\title{
Organizational Care Impact on Work Commitment: A Study in the Health Care Field
}

\author{
Wajiha Iffat'1, Sadia Shakeel ${ }^{*}$, Faraz Siddiqui'2, Muhammad Rehan² \\ ${ }^{1}$ Dow College of Pharmacy, Dow University of Health Sciences, Karachi, Pakistan \\ ${ }^{2}$ Institute of Nursing, Dow University of Health Sciences, Karachi, Pakistan \\ Email: "sadia.shakeel@duhs.edu.pk
}

Received 12 October 2015; accepted 28 October 2015; published 3 November 2015

Copyright (C) 2015 by authors and OALib.

This work is licensed under the Creative Commons Attribution International License (CC BY). http://creativecommons.org/licenses/by/4.0/

(c) (i) Open Access

\section{Abstract}

In recent time, organizational trust is an increasingly important component in determining employee commitment to the organization. The current study was conducted with the aim to determine the impact of organizational care on work commitment of healthcare professionals. A cross sectional study was carried out during the span of February to August 2015 to assess the impact of organizational care on work commitment amongst healthcare professionals of tertiary care facilities in Karachi. The study included a sample of 187 healthcare professionals rendering their services in different tertiary care facilities of Karachi. Descriptive statistics were used to demonstrate participants' demographic information and their response to the questionnaire items. To observe the influence of age, gender, type of organization, job status and salary on the responses, one way ANOVA was adopted, using $p<0.05$ level of significance. Our findings revealed that mass population (71\%) felt honored to be the part of their organization. $72 \%$ opined that in their organization employee got promoted on the basis of their seniority. 68\% of the respondents did not agree that their work load was manageable and they felt under pressure to perform well. 0nly 33\% agreed that they were assigned task that provided opportunity to utilize their knowledge and educational background and their day to day task was related to their capabilities and skills. Public health professionals' commitment to their jobs would determine the quality of the service delivery for their respective communities. This study will assist policy makers to trigger those factors that increase levels of work commitment among health care professionals.

\section{Keywords}

Work Commitment, Healthcare Professionals, Organizational Care, Karachi

Subject Areas: Organizational Behavior and Theory

\footnotetext{
${ }^{*}$ Corresponding author.
} 


\section{Introduction}

Organizational commitment is an important variable to consider in light of the high costs associated with turnover. It has been defined as "a psychological link between the employee and his or her organization that makes it less likely that the employee will voluntarily leave the organization”. Commitment relates to an employee's attachment, identification and involvement with the organization. Employees with strong organizational commitment stay with the organization because they want to [1]. Organizational commitment has been positively related to job performance, organizational citizenship behaviors and job satisfaction [2]. Six areas of work life (workload, control, rewards, community, fairness and values) act as organizational antecedents of employee engagement or burnout [3]. Much of the interest in organizational commitment stems from reports of positive consequences on employee behavior and desirable work outcomes from organizational commitment.

In clinical sciences, physicians' satisfaction plays a great role in their performance and therefore is reflected as satisfaction and compliance among their patients. Similarly, public health professionals' satisfaction in their jobs would determine the quality of the service delivery for their respective communities. Satisfaction of job among health care professionals (HCPs) is a vital part of ensuring their high concern in the profession they are engaged in. The rapid changes in medical practice in the past quarter century have stimulated considerable interest in measuring HCPs perceptions and attitudes about their work [4]. Low levels of job satisfaction among HCPs may affect HCPs-patient relationships and compromise quality of care. High quality patient care requires the presence of a committed workforce that is fully engaged in its work and settings that empower them to provide the care they are educated to provide. Dissatisfaction with professional work among HCPs has also been associated with inappropriate prescribing patterns, lower levels of patient satisfaction, and decreased patient compliance with prescribed medications and follow-up appointments [5]. HCPs turnover is also greater in organizations with higher levels of dissatisfaction. High turnover can disrupt continuity of care and can increase costs. Finally, high levels of dissatisfaction decrease HCPs commitment to the practice setting and, if persistent, can lead to mental strain and burnout [6]. We aimed to assess the level of and determine the factors influencing work commitment amongst health care professionals working in tertiary care health settings of Karachi.

\section{Materials and Methods}

It was a cross sectional study carried out during the span of February to August 2015. The study population comprised of HCPs working in tertiary care hospitals of Karachi. Sampling techniques of the study were nonsystematic randomized. Questionnaires were distributed in different charitable and non-charitable tertiary care hospitals of Karachi. The basic tool selected to conduct the study was questionnaire which was developed through the review of literature and researches available in this area. The questionnaire was designed in a way that it comprises of two portions. First portion consists on demographics associated 5 questions. The second portion had 22 questions to assess the impact of organizational care on job performance amongst health care professionals. Items rated on a Likert scale ranging from 1 = strongly disagree to 5 = strongly agree. Prior verbal ethical approval was taken from each institution's head of department to instigate the study in their institute. Each institution's head of department and the health care professionals' participating in the study were briefed about the rationale of the study. Participants were assured about the confidentiality of their personal information and responses. The filled questionnaires were analyzed by using SPSS 20.0. Descriptive statistics were used to demonstrate participants' demographic information and their response to the questionnaire items. To observe the influence of age, gender, type of organization, job status and salary on the responses, one way ANOVA was adopted, using $p<0.05$ level of significance.

\section{Results and Discussion}

Out of 250 survey questionnaires, only 187 were returned back in useable form. Hence the response rate was $74.8 \%$. Table 1 showed the demographic of the study population. The study population comprised of $69 \%$ males and $31 \%$ females. Near about $46 \%$ of the participants belonged to the public sector and 54\% belonged to private sector hospitals. Mass population 78\% was rendering their services on permanent basis and $42 \%$ was earning more than 50,000 PKR.

Table 2 revealed the opinion of healthcare professionals towards questionnaire items. Mass population (71\%) feel honored to be the part of their organization. $72 \%$ opined that in their organization employee gets promoted 
Table 1. Characteristics of study population.

\begin{tabular}{|c|c|c|}
\hline S. No & Characteristics & Percentages \\
\hline \multirow[t]{3}{*}{1} & Gender & \\
\hline & Male & 69 \\
\hline & Female & 31 \\
\hline \multirow[t]{6}{*}{2} & Age & \\
\hline & $25-30$ yrs & 36 \\
\hline & $31-35$ yrs & 22.4 \\
\hline & $36-40$ yrs & 12 \\
\hline & $41-50 \mathrm{yrs}$ & 14.4 \\
\hline & 51 and above & 15.2 \\
\hline \multirow[t]{3}{*}{3} & Type of organization & \\
\hline & Private & 54 \\
\hline & Public & 46 \\
\hline \multirow[t]{3}{*}{4} & Job status & \\
\hline & Permanent & 78 \\
\hline & Contract & 22 \\
\hline \multirow[t]{7}{*}{5} & Salaries (PKR) & \\
\hline & $5000-10,000$ & 4 \\
\hline & $10,000-20,000$ & 9 \\
\hline & $20,000-30,000$ & 11 \\
\hline & $30,000-40,000$ & 19 \\
\hline & $50,000 \&+$ & 42 \\
\hline & Unanswered & 15 \\
\hline
\end{tabular}

Table 2. Opinion of healthcare professionals towards questionnaire items.

\begin{tabular}{ccccccc}
\hline S. No & Items & $\begin{array}{c}\text { Strongly } \\
\text { agree }\end{array}$ & Agree & $\begin{array}{c}\text { Neutral } \\
\text { Disagree }\end{array}$ & $\begin{array}{c}\text { Strongly } \\
\text { disagree }\end{array}$ \\
\hline 1 & My organization provides job security & 1 & 17 & 16 & 39 & 27 \\
2 & I have good relationship with my superiors & 10 & 3 & 24 & 32 & 31 \\
3 & I have good relationship with my subordinates & 19 & 33 & 12 & 19 & 17 \\
4 & I feel honored to be the part of this organization & 7 & 71 & 8 & 12 & 2 \\
5 & I get the work done on time & 5 & 26 & 25 & 37 & 7 \\
6 & My work load is manageable & 1 & 5 & 25 & 60 & 8 \\
7 & I feel under pressure to perform well & 6 & 18 & 14 & 48 & 14 \\
9 & My in and out timing are well defined & 9 & 49 & 15 & 22 & 5 \\
10 & I have to work extra hours to get job done & 21 & 41 & 15 & 18 & 5 \\
\hline
\end{tabular}




\begin{tabular}{|c|c|c|c|c|c|c|}
\hline \multicolumn{7}{|c|}{ Continued } \\
\hline 11 & $\begin{array}{l}\text { Whenever my organization makes any key decision } \\
\text { my opinion is considered }\end{array}$ & 4 & 9 & 23 & 43 & 21 \\
\hline 12 & $\begin{array}{l}\text { My organization welcomes their employee’s } \\
\text { suggestion for improvement }\end{array}$ & 9 & 22 & 28 & 35 & 6 \\
\hline 13 & My suggestion for organization betterment was implemented & 18 & 11 & 3 & 56 & 12 \\
\hline 14 & $\begin{array}{l}\text { In my organization Employee gets promoted on } \\
\text { the basis of their seniority }\end{array}$ & 11 & 61 & 4 & 17 & 7 \\
\hline 15 & $\begin{array}{l}\text { In my organization Employee get promoted on the basis } \\
\text { of their qualification and quality of work }\end{array}$ & 20 & 38 & 25 & 8 & 9 \\
\hline 16 & My organization makes key decision without involving employees & 17 & 58 & 12 & 9 & 4 \\
\hline 17 & My day to day task are related to my capabilities and skills & 21 & 12 & 1 & 57 & 9 \\
\hline 18 & My jobs provides work diversity & 24 & 10 & 8 & 2 & 56 \\
\hline 19 & My job provides me to interact with different people & 16 & 69 & 11 & 1 & 3 \\
\hline 20 & I enjoy doing my day to day task & 29 & 8 & 8 & 53 & 2 \\
\hline 21 & My organization communication channels are well defined & 12 & 24 & 5 & 54 & 5 \\
\hline 22 & $\begin{array}{l}\text { I am assigned task that provide me opportunity to utilize } \\
\text { my knowledge and educational background }\end{array}$ & 15 & 18 & 1 & 13 & 53 \\
\hline
\end{tabular}

on the basis of their seniority whereas more than half opined that employee get promoted on the basis of their qualification and quality of work.

Rousseau suggests the key to strengthening employees' psychological attachment in the contemporary workplace is to either reinforce perceptions of organizational membership or demonstrate organizational care and support for employees, or both. Strong perceptions of organizational membership exist when individuals and the organization have common interests, and individuals perceive that their relationship with the organization forms an "us" [7]. In our study, 64\% of participants opined whenever organization makes any key decision their opinion is considered. 68\% did not agree that their work load is manageable and they feel under pressure to perform well. Research has shown that because of a growing emphasis on learning in today's careers, opportunity for learning at work may be an important determinant of employees' job attitudes and behaviors. Because opportunity for learning at work is increasingly desired by employees today, its provision should help elicit employees' perceptions of a quality relational exchange with their employers and therefore reciprocation in terms of organizational commitment [8]. In current study, only 33\% agreed that they are assigned task that provide opportunity to utilize their knowledge and educational background and their day to day task is related to their capabilities and skills. While only $37 \%$ enjoy doing their day to day task. $31 \%$ have an opinion that organization welcomes their suggestion for improvement whereas only $29 \%$ said that their suggestion for organization betterment was implemented.

The importance of job security stems from the fact that it is critical for influencing work-related outcomes. For instance, job security is an important determinant of employee health; for the physical and psychological wellbeing of employees; for employee turnover; for employee retention; for job satisfaction; and for organizational commitment [9]. However in our study only $18 \%$ agreed that their organization provides job security. Ashford examined the impact of job insecurity on organizational commitment, job satisfaction, and job performance. They reported that job insecurity leads to reduced commitment and reduced satisfaction, but it has no impact on job performance [10]. Iverson also reported that increases in job security lead to greater organizational commitment [11]. Other study conducted in Pakistan also revealed that public health professionals reported low satisfaction with professional development opportunities, recognition, poor salaries and benefits, not being involved in decision making, doing a lot of irrelevant task and having sufficient time pressure [12]. Employees' needs and motivators differ so it is significant to recognize what motivates them to execute their activities.

Supportive relations at work may be critically important to the maintenance of psychological well-being and physical health. Researchers investigating the workplace have long recognized social support and the closely related concepts of interpersonal warmth, trust, and openness as core dimensions of organizational or communica- 
tion climate that may affect many organizational outcomes, including job satisfaction and performance. The lack of understanding between subordinates and superiors may account for some of the inconclusiveness in some areas as motivation, leadership, and performance appraisal. This seems particularly true concerning the association between performance and rewards [13]. In current study only $13 \%$ have good relationship with superiors. However, more than $50 \%$ has good relationship with subordinates. To observe the influence of age, gender, type of organization, job status and salary on the responses, one way ANOVA was adopted using $p<0.05$ level of significance (Table 3).

Table 3. Influence of age, gender, type of organization, job status and salary on the responses.

\begin{tabular}{|c|c|c|c|}
\hline S. No & Items & $\mathbf{F}$ & Sig. \\
\hline 1 & Q-3 vs age & 1.764 & 0.028 \\
\hline 2 & Q-14 vs gender & 8.922 & 0.035 \\
\hline 3 & Q-18 vs gender & 5.675 & 0.043 \\
\hline 4 & Q-22 vs gender & 5.109 & 0.021 \\
\hline 5 & Q-1 vs type of organization & 5.205 & 0.007 \\
\hline 6 & Q-12 vs type of organization & 8.599 & 0.0001 \\
\hline 7 & Q-13 vs type of organization & 7.432 & 0.001 \\
\hline 8 & Q-14 vs type of organization & 4.545 & 0.013 \\
\hline 9 & Q-18 vs type of organization & 5.86 & 0.004 \\
\hline 10 & Q-19 vs type of organization & 7.767 & 0.001 \\
\hline 11 & Q-3 vs job status & 6.566 & 0.012 \\
\hline 12 & Q-9 vs job status & 5.964 & 0.016 \\
\hline 13 & Q-10 vs job status & 12.965 & 0.001 \\
\hline 14 & Q-14 vs job status & 4.253 & 0.042 \\
\hline 15 & Q-16 vs job status & 7.145 & 0.009 \\
\hline 16 & Q-17 vs job status & 11.242 & 0.001 \\
\hline 17 & Q-18 vs job status & 5.221 & 0.024 \\
\hline 18 & Q-19 vs job status & 7.382 & 0.008 \\
\hline 19 & Q-20 vs job status & 3.946 & 0.05 \\
\hline 20 & Q-21 vs job status & 22.497 & 0.0001 \\
\hline 21 & Q-22 vs job status & 11.219 & 0.001 \\
\hline 22 & Q-7 vs salary & 2.491 & 0.036 \\
\hline 23 & Q-10 vs salary & 3.215 & 0.01 \\
\hline 24 & Q-11 vs salary & 3.166 & 0.011 \\
\hline 25 & Q-13 vs salary & 3.04 & 0.014 \\
\hline 26 & Q-17 vs salary & 3.04 & 0.014 \\
\hline 27 & Q-18 vs salary & 2.458 & 0.039 \\
\hline 28 & Q-22 vs salary & 2.808 & 0.021 \\
\hline
\end{tabular}




\section{Conclusion}

Public health professionals’ commitment to their jobs would determine the quality of the service delivery for their respective communities. Our findings suggest the interventions of policy makers to trigger those factors that increase levels of work commitment among health care professionals.

\section{Acknowledgements}

The authors wish to acknowledge Natasha Arif, Amin-Ur-Rehman and Nida Gul for their support in compiling the data.

\section{Conflict of Interest}

Authors declare no conflict of interest.

\section{References}

[1] Piko, B.F. (2006) Burnout, Role Conflict, Job Satisfaction and Psychosocial Health among Hungarian Health Care Staff: A Questionnaire Survey. International Journal of Nursing Studies, 43, 311-318. http://dx.doi.org/10.1016/j.ijnurstu.2005.05.003

[2] Hackett, R.D., Lapierre, L.M. and Hausdorf, P.A. (2001) Understanding the Links between Work Commitment Constructs. Journal of Vocational Behavior, 58, 392-413. http://dx.doi.org/10.1006/jvbe.2000.1776

[3] Cho, J., Laschinger, H.S. and Wong, C. (2006) Workplace Empowerment, Work Engagement and Organizational Commitment of New Graduate Nurses. Nursing Leadership-Academy of Canadian Executive Nurses, 19, 43. http://dx.doi.org/10.12927/cjnl.2006.18368

[4] Kaldenberg, D.O., Becker, B.W. and Zvonkovic, A. (1995) Work and Commitment among Young Professionals: A Study of Male and Female Dentists. Human Relations, 48, 1355-1377. http://dx.doi.org/10.1177/001872679504801106

[5] Baker, L.C. and Cantor, J.C. (1993) Physician Satisfaction under Managed Care. Health Affairs, 12, $258-270$. http://dx.doi.org/10.1377/hlthaff.12.suppl_1.258

[6] Deckard, G., Meterko, M. and Field, D. (1994) Physician Burnout: An Examination of Personal, Professional, and Organizational Relationships. Medical Care, 745-754. http://dx.doi.org/10.1097/00005650-199407000-00007

[7] Rousseau, D.M. (2004) Psychological Contracts in the Workplace: Understanding the Ties That Motivate. The Academy of Management Executive, 18, 120-127. http://dx.doi.org/10.5465/AME.2004.12689213

[8] Lankau, M.J. and Scandura, T.A. (2002) An Investigation of Personal Learning in Mentoring Relationships: Content, Antecedents, and Consequences. Academy of Management Journal, 45, 779-790. http://dx.doi.org/10.2307/3069311

[9] Yousef, D.A. (1998) Satisfaction with Job Security as a Predictor of Organizational Commitment and Job Performance in a Multicultural Environment. International Journal of Manpower, 19, 184-194. http://dx.doi.org/10.1108/01437729810216694

[10] Ashford, S.J., Lee, C. and Bobko, P. (1989) Content, Cause, and Consequences of Job Insecurity: A Theory-Based Measure and Substantive Test. Academy of Management Journal, 32, 803-829. http://dx.doi.org/10.2307/256569

[11] Iverson, R.D. (1996) Employee Acceptance of Organizational Change: The Role of Organizational Commitment. International Journal of Human Resource Management, 7, 122-149.

[12] Kumar, R., Ahmed, J., Shaikh, B.T., Hafeez, R. and Hafeez, A. (2013) Job Satisfaction among Public Health Professionals Working in Public Sector: A Cross Sectional Study from Pakistan. Human Resources for Health, 11, 2. http://dx.doi.org/10.1186/1478-4491-11-2

[13] Kirmeyer, S.L. and Lin, T.-R. (1987) Social Support: Its Relationship to Observed Communication with Peers and Superiors. Academy of Management Journal, 30, 138-151. http://dx.doi.org/10.2307/255900 